

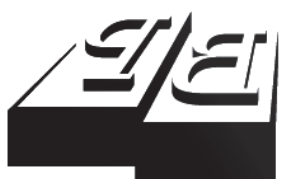

BUSINESS PERSPECTIVES

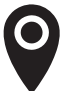

LLC "CPC "Business Perspectives" Hryhorii Skovoroda lane, 10, Sumy, 40022, Ukraine

www.businessperspectives.org

Received on: $10^{\text {th }}$ of June, 2017

Accepted on: $14^{\text {th }}$ of July, 2017

(c) Kgabo L. Kobo, Collins C.

Ngwakwe, 2017

Kgabo L. Kobo, MBA Student, Turfloop Graduate School of Leadership, Faculty of Management and Law, University of Limpopo, South Africa.

Collins C. Ngwakwe, Professor, Turfloop Graduate School of Leadership, Faculty of Management and Law, University of Limpopo, South Africa.

\section{RELATING CORPORATE SOCIAL INVESTMENT WITH FINANCIAL PERFORMANCE}

\begin{abstract}
Previous researchers have found conflicting results between CSI and firm financial performance. This paper moves this debate further by examining the extent to which corporate social investment (CSI) relates with corporate financial performance (CFP) from a developing country perspective. The main aim of the paper was to determine the relationship between CSI, stock price, sales turnover and return on equity (ROE) amongst the socially responsible investing (SRI) companies in the Johannesburg Stock Exchange. CSI data on the SRI companies were collected from companies' integrated reports from 2011 to 2015. Therefore, a cross-sectional panel data arrangement was applied and the analysis was conducted using the ordinary least square (OLS). Tested at an alpha level of 0.05 , the regression result produced a probability level of $\mathrm{P}<0.01$ for share price and sales turnover; and $\mathrm{P}=10$ for return on equity. Therefore, the findings revealed a strong positive and significant linkage between the SRI companies' social investment, share price and sales turnover and no significant linkage with return on equity. These findings are consistent with previous literature findings reviewed in the paper on similar research conducted in developed countries, which showed positive and negative relationships. Findings from the literature indicate that various factors may account for conflicting results, which includes inter alia, time coverage, size of data, location, market sustainability awareness and culture. The paper contributes by revealing that whilst CSI may trigger improvement in stock price and sales turnover of SRI companies, the sales turnover might not necessarily result in boost in profit level that could engender enough return on equity within a short period time. The conflicting results from the literature is indicative of the inclusiveness in research between CSI and firm performance. Hence, the paper recommends further research to examine the relationship within a longer period of time using new sample of companies and other methods of analysis.
\end{abstract}

\section{Keywords}

sustainable responsibility, corporate social investment, socially responsible investment, stock price, sales turnover, return on equity, financial performance

\section{JEL Classification $\quad$ M11, M41}

\section{INTRODUCTION}

Corporate operations have largely been criticized for contributing to social, environmental, and economic problems (Franks et al., 2014). These burning issues need the intervention from government and non-governmental organizations (NGOs). There are also increased demands from the consumer for corporates to take responsibility of their operational activities which have negative consequences for the society and the environment. Corporates should find better way of conducting their businesses while maintaining responsibility and sustainability (Porter \& Kramer, 2011).

Corporate social investment occurs when companies voluntarily incorporate economic, social, and environmental initiatives in their daily operations and activities to cater for the wellbeing of various stake-
This is an Open Access article, distributed under the terms of the Creative Commons Attribution 4.0 International license, which permits unrestricted re-use, distribution, and reproduction in any medium, provided the original work is properly cited. 
holders of business (Adams et al., 2016; European Commission, 2001). Although corporate social investment (CSI) has received diverse definitions, all of them point to one central point, which is the ability of business to achieve profit objective whilst contributing to the social wellbeing of the business community (Bowen, 2013). Although the advent of corporate social responsibility movement has planted a sense of responsibility on business to include social issues in their strategic planning, CSI remains largely a voluntary initiative with little regulation and/or enforcement (Bhimani et al., 2016; Lee et al., 2017; Yakovleva et al., 2017). This thus makes it difficult to coerce the corporate into CSI engagements. Accordingly, the attention of corporate executives toward CSI may occur with persuasive strategies from researchers and social activists; such persuasion strategies must demonstrate the likelihood that the corporate would increase its value through engagement in CSI; this is because the primary objective of the corporate is profit to justify the investment made by investors (Hirsch, 2017; Friedman, 2007). Based on the foregoing premise, researchers have been examining the value relevance of CSI for companies to motivate the corporate toward improved CSI. Many previous researcherers have thus tried to link corporate social initiatives on various measures of firm performance, which includes, inter alia, net profit, share price, sales turnover, return on equity, return on asset (Manchiraju \& Rajgopal, 2017; Firli \& Akbar, 2016). However, what is outstanding in these previous researches is the preponderance on developed countries. This paper therefore adds to the existing literature by examining if CSI is relating to firm financial performance in a developing country such as South Africa. This is justified given acclaimed existence of wide social inequity in South Africa, which arose from many years of colonial suppression of the greater number of citizens. Thus, corporate CSI engagement in South Africa becomes an attractive subject of study to inform and motivate more companies into CSI initiatives. In this paper, three proxies of financial performance has been chosen - share price, sales turnover and return on equity. Research on corporate social investment and financial performance within the South African context and specifically within the socially responsible index of the Johannesburg Stock Exchange (JSE) with a combination of these three dependent financial variables is not common. Therefore, the objectives of this paper are three-fold: to evaluate the how corporate social investment relates with sales turnover, return on equity and share price.

After the foregoing introduction, the next section of the paper presents a review of related literature, which addresses the theme of this paper. Following the literature section is the methodology, the results and discussion of results. The final section is the conclusion and recommendations.

\section{RELATED LITERATURE}

Corporate social investment (CSI) is commonly regarded as a business commitment, which might come in form of financial assistance, material gifts to community, or other forms of corporate resources including time committed to assist the community, which, in return, might add value to the company within the short or long run (Mondi, 2012). In the same vein, others summarize corporate social investment in a closely similar description as initiatives taken by the corporate to help communities achieve their developmental goals (Adams et al., 2016). It is therefore clear that CSI is any form of business commitment to society in expectation of value to the business. This value expectancy is important given that the business is established to make profit for its owners (Quora, 2015).

Extant research has attempted to motivate and persuade corporate commitment to social initiatives by providing empirical evidence of firm performance improvements that arise from corporate social initiatives and/or investments. However, many of such researches have had diverse findings with significant or neutral relationships (Kecskes et al., 2016), hence, efforts to explore relationships between these important corporate social and firm performance remain inconclusive and yearns for continuous research (Wang et al., 2016).

In their study on shareholder value implication of corporate social responsibility, Kecskes et al. (2016) 
found that corporate social responsibility has the propensity to improve shareholder value; but this may be realized if investors are able to monitor the activities of managers.

It has also been found that companies with high level of social capital develop trust that makes such companies have more resilient capacity to withstand shocks during periods of financial market crises (Lins et al., 2016). The summary of Lins et al's. (2016) research indicates that companies with high commitment in corporate social responsibility tend to experience financial improvements such as higher stock returns, increased sales and improved profits.

Positive link between corporate investment, as well as firm's financial performance, was also established by Alafi and Hasoneh (2012).

In another spectrum of research, the timing of CSI and accruable benefit to the company has also received the attention of researchers. This inquisition is because in conventional project investments, not all investments would begin yielding benefit at the onset of the initial investment (Henderson, 2015). In investment analysis, some project alternatives may begin a year after; others may begin yielding benefit even after two years or more. Such investment behavior has thus been likened to CSI and researchers have found similar trends in associated benefit with corporate CSI. Therefore, whilst some companies may experience immediate financial return, it might take others some years to reap the benefits of corporate social investment. Such investment could also be a proactive strategy to cushion future environmental trends (Henderson, 2015). According to findings from other research, in the early period of CSI, company's profitability might be affected negatively, but, at some point, the effect might be reverse and profitability will begin to experience a positive trend by additional CSI engagement (Barnett \& Salomon, 2012).

This was confirmed earlier by researchers such as Blackburn et al. (1994) and Callan et al. (2009).

A boost in sales revenue might kick off after few years of continuous social investment initiative (Blackburn et at., 1994); in their findings, it takes a period of one year to start detecting the fiscal improvement after an active social investment act (Callan et al., 2009).

Charlo et al. (2015) applied empirical evaluation to assess differences in financial performance indicators of two major subsets of industry. In their study, they divided companies into socially responsible and irresponsible companies. Their findings showed that companies that are more socially engaged or responsible experience more profitability than companies that show less concern for social responsibility (Charlo et al., 2015). Other related research has also found positive relationship between CSI and firm financial performance, but with an added emphasis on the effect that managerial skill has to play. It is found that companies with higher managerial skill are more prone to experience positive benefit from CSI, since their skill assists in making proper decisions regarding CSI initiatives (DeMaCarty, 2009). This thus shows that physical and financial resources should be backed by managerial skill to reap the reward of CSI. Other studies have found contradictory results. The linkage of corporate social investment and firm's financial performance has been examined by numerous scholar previously, some of these studies did not find a significant relationship (Ağan et al., 2016; Hubbard et al., 2017).

Another group of researchers have examined how corporate social responsibility might play a role in stock price crash risk. For instance, after controlling for other factors that might affect crash risk, Kim et al. (2014) found that higher engagement with corporate social responsibility has great propensity to cushion socially responsible companies against potential crash risk. Importantly, their research found that such protection is more noticeable in companies with weak corporate boards or weak corporate governance (Kim et al., 2014).

De Klerk et al. (2015) evaluated the role of CSI or companies' stock price using in the 100 large companies in United Kingdom. The statistical result from their analysis showed that companies with higher devotion to corporate social investment experience higher share prices than companies with low commitment to CSI. Their findings also indicate that companies in more environmentally sensitive companies seem to 
attract higher share price when engaged in CSI than their counterparts in less environmentally sensitive industries (De Klerk et al., 2015).

Stockholders react satisfactorily towards the stock prices of firms with corporate social investment strategy (Falck \& Heblich, 2007). Shareholders value corporate social investment, because they believe that firms in the process of taking care of their many different stakeholders may actually attract shareholders that will end up buying their stock and thus increasing share returns (Stout, 2012). Similarly, a linkage have been found between corporate social responsibility, return on equity and return on asset (Okoth, 2012). Economically, the benefit of CSI program is an increase in company revenue (Orlitzky et al., 2003).

This current paper stands out from other previous studies, as it looks at how CSI relates with financial performance five years following the release of King III code of corporate governance in South Africa.

In another research conducted in the US, Giannarakis et al. (2016) investigated how CSR related with the financial performance of selected US companies using the Bloomberg social performance scores. Using a fixed effect regression analysis, their findings show a significant and positive influence of CSR on financial performance. Related to this finding is a close research by the same authors in 2017, in which they analyzed the relationship between sustainability index and consumer confidence, using an autoregressive model and data from the Dow Jones Sustainability Index, the regression results show a relationship between sustainability index and consumer confidence (Giannarakis et al., 2017). Another study has investigated whether an investment strategy under CSR can enhance financial performance. In their research on R\&D-CSR based companies, using the Tobin's $Q$ as a measure of financial performance and applying the Logit regression method, YuChun (2017) examined the relationship between R\&D investment under CSR and financial performance, the regression results show a positive relationship between R\&D under CSR and financial performance in a sample of Taiwanese companies. These preceding findings also have support by other researchers such as Henry et al. (2017), which allude to a relationship between CSR and firm performance.

Apart from the foregoing positive findings, other research documents a negative relationship between CSR and firm performance. In another related study, Nakashima and Ota (2016) examined the corporate social responsibility (CSR) relationship with financial performance in Japanese companies; using a panel regression analysis, their findings show a significant and negative relationship between CSR and financial performance. Lakshitha and Perera (2016) evaluated how CSR relates with financial performance amongst 32 listed companies in Sri Lanka. Applying a regression and correlation analysis, their findings show a significant negative relationship between companies' engagement in CSR and their financial performance represented by net profit and return on assets.

The South African King III report on corporate governance specified, amongst others, the need to integrate sustainability report in corporate financial statement to enable all stakeholders to understand how the companies have dealt with the society and environment. Part of this sustainability report is corporate social responsibility couched in social investment. The Johannesburg Stock Exchange Limited (JSE) thus adopted the Kind III sustainability report recommendation, which was released in 2009 and became effective in 2010. The JSE thus required its listed companies to comply with the requirements of integrating sustainability report into their financial statements or explain why they have not been able to do so (Solomon \& Maroun, 2012; IDS, 2013). Therefore, the King III requirement on sustainability disclosure, which includes the disclosure of corporate social investment, enables researchers to collect data on the SRI companies' social investment from companies that comply and disclose such data.

\section{METHOD}

This paper adopted a quantitative approach by employing a panel data regression analysis. This research applied a non-probability sampling as it targeted a certain element of a popu- 
lation that exhibits a unique trait; in this case, the research targeted the SRI Index companies which known for their social initiatives. Thus, in non-probability sampling, the sample size selection would depend on the basis of data availability (see, e.g., Herek, 2012). In science, researchers may use a single example to proffer or refute an argument Herek (2012) subject to further corroboration or rebuttal. The paper adopted a purposive sampling method and, therefore, purposefully chose companies listed as the best socially responsible investing performers in the Johannesburg Stock Exchange (JSE) Socially Responsible Investing Index (SRI) released in 2015 as the research population. The choice of this purposive selection of population is justified, since this research dwells on social investment; hence, the companies ranked by the JSE as those who perform social investment are the best companies to use in conducting the research, as these are the companies from where data can be sought. There were nine companies listed as the best SRI performers by the JSE released in 2015. The researchers chose to study all the nine companies; however, the sample came down to five due to social investment data availability on all the nine companies for the period 2011-2015. Therefore, five companies that maintained a continuous reporting of social investment data were used as the sample (which is $56 \%$ of the population). Hence, the justification for choosing the five companies from the Johannesburg Socially Responsible Investing Index (SRI) is that these companies reported social investment data consecutively for five years (2011-2015). This selection is consistent with research recommendation that research, which measures the CSR-financial performance relationship, should indicate a clear analysis with indicative boundaries to enable results to speak to such boundaries and for easy replication (Perrini et al., 2011; Hirschheim, Heinzl, \& Dibbern, 2009, p. 237). This research tried to adhere to this suggestion by focusing its boundary on the best JSE SRI firms and also focussing on those firms that reported consecutively their social investment from 2011-2015. Thus, the number of such firms was five. The proxy for corporate social investment in this research was their early corporate social expenditure as reported by companies. Data were collected from the integrated report of the sample of five companies used in the study. The proxies used for financial performance were share price, sales turnover and return on equity. During the period of five years under study, the financial performance of these companies (share price and sales turnover) assumed an upward trend and retained the trend through the period. However, the return on equity (ROE) for the five companies, assumed a rising trend initially but declined sharply afterwards. Since five companies were studied over five years, the cross sectional panel data produced 25 observations, which is 5 cross sectional units by 5 years. 2011 was chosen as the starting year, because, as indicated in the preceding sections, the King III report on South Africa's corporate governance was released in 2009 and became effective for companies reporting of CSI in 2010. The researchers thought it was reasonable that many companies may have used 2009 and 2010 to improve their CSI engagement to warrant reporting; hence, the researchers chose 2011 as an objective year to begin observing CSI engagement in companies under study. As said earlier, the South African King III Code of Corporate Governance recommended the integration of sustainability reports (including social investment reports) into the normal financial statement to enable stakeholders to see how the companies engage with society and environment. The JSE adopted the King III recommendations and also recommended that listed companies should disclose sustainability initiatives or explain why they would not comply. Based on this King III recommended disclosures, researchers are able to collect CSI data from complying companies.

The following simple regression model was applied in the statistical analysis:

$$
\gamma=\beta_{0}+\beta_{1} \cdot \chi_{1}+\varepsilon
$$

where $\gamma$ - the company's financial performance (share price, sales turnover and return on equity, respectively);

$\beta_{0}$ - the intercept, $\beta_{1}$ - regression coefficient, $\chi_{1}$ - CSI (represented by annual corporate social expenditure), $\varepsilon$ - error term takes care of other independent variables not included in this analysis. 


\section{RESULTS}

Table 1. Link between corporate social investment (CSI) and share price (ShP) of those companies

Model 1. Fixed-effects using 25 observations Included 5 cross-sectional units

Time-series length $=5$

Dependent variable: ShP (share price)

\begin{tabular}{|c|c|c|c|c|c|}
\hline & Coefficient & Std. Error & t-ratio & p-value & \\
\hline const & 36.8522 & 33.1689 & 1.1110 & 0.28041 & \\
\hline CSI & 1.41178 & 0.287367 & 4.9128 & 0.00010 & $* * *$ \\
\hline Mean dependent var & & 158.8016 & S.D. dependent var & & 148.9715 \\
\hline Sum squared resid & & 229903.6 & S.E. of regression & & 110.0009 \\
\hline R-squared & & 0.568354 & Adjusted R-squared & & 0.454763 \\
\hline$F(5,19)$ & & 5.003508 & P-value (F) & & 0.004314 \\
\hline Log-likelihood & & -149.5552 & Akaike criterion & & 311.1104 \\
\hline Schwarz criterion & & 318.4237 & Hannan-Quinn & & 313.1388 \\
\hline Rho & & -0.388592 & Durbin-Watson & & 2.443620 \\
\hline
\end{tabular}

Table 2. Association between corporate social investment (CSI) and turnover

Model 2. Fixed-effects, using 25 observations

Included 5 cross-sectional units

Time-series length $=5$

Dependent variable: sales turnover

\begin{tabular}{|c|c|c|c|c|c|}
\hline & Coefficient & Std. Error & t-ratio & p-value & \\
\hline Const & 13.8296 & 2.38701 & 5.7937 & 0.00001 & $* * *$ \\
\hline CSI & 0.130711 & 0.0206804 & 6.3205 & 0.00001 & $* * *$ \\
\hline Mean dependent var & & 25.12040 & S.D. dependent var & & 12.53935 \\
\hline Sum squared resid & & 1190.668 & S.E. of regression & & 7.916232 \\
\hline R-squared & & 0.684478 & Adjusted R-squared & & 0.601446 \\
\hline$F(5,19)$ & & 8.243543 & P-value (F) & & 0.000279 \\
\hline Log-likelihood & & -83.76589 & Akaike criterion & & 179.5318 \\
\hline Schwarz criterion & & 186.8450 & Hannan-Quinn & & 181.5602 \\
\hline Rho & & -0.144913 & Durbin-Watson & & 1.652171 \\
\hline
\end{tabular}

Table 3. Relationship exists between corporate social investment (CSI) and return on equity

Model 3. Fixed-effects, using 25 observations

Included 5 cross-sectional units

Time-series length $=5$

Dependent variable: ROE (return on equity)

\begin{tabular}{|c|c|c|c|c|c|}
\hline & Coefficient & Std. Error & t-ratio & p-value & \\
\hline Const & 26.125 & 8.20378 & 3.1845 & 0.00488 & $* * *$ \\
\hline CSI & 0.119965 & 0.0710754 & 1.6879 & 0.10779 & \\
\hline Mean dependent var & & 36.48760 & S.D. dependent var & & 27.71724 \\
\hline Sum squared resid & & 14064.10 & S.E. of regression & & 27.20691 \\
\hline R-squared & & 0.237217 & Adjusted R-squared & & 0.036485 \\
\hline$F(5,19)$ & & 1.181760 & P-value (F) & & 0.354633 \\
\hline Log-likelihood & & -114.6298 & Akaike criterion & & 241.2595 \\
\hline Schwarz criterion & & 248.5728 & Hannan-Quinn & & 243.2879 \\
\hline Rho & & 0.118308 & Durbin-Watson & & 1.526427 \\
\hline
\end{tabular}


Table 4. Interpretation of results

\begin{tabular}{l|c|c}
\hline \multicolumn{1}{c}{ Objective } & Table & Finding (p-value) \\
\hline Relationship between CSI and share price & Table 1 & $\mathrm{P}=0.00010$ \\
Relationship between CSI and sales turnover & Table 2 & $\mathrm{P}=0.00001$ \\
Relationship between CSI and return on equity & Table 3 & $\mathrm{P}=0.10779$ \\
\hline
\end{tabular}

In other to provide an answer to the three objectives of this paper, previous research literature were reviewed in the preceding literature sections. Findings from the literature indicate conflicting results; some previous researches found positive relationship between CSI and financial performance (e.g., Giannarakis et al., 2017; YuChun, 2017; Reverte et al., 2016). Other previous empirical research found negative relationship between CSI and corporate financial performance (e.g., Nakashima \& Ota, 2016; Lakshitha \& Perera, 2016).

In addition to the literature findings, Tables 1-3 presented the panel data regression results, which addressed the three different objectives of the paper. Table 1 shows the statistical result for the relationship between CSI and share price; the result shows a positive p-value of 0.001 , which means that within the five companies used as sample over five years, the companies experienced a positive and significant linkage between the level of CSI and companies' share price. Similarly, Table 2, which tested the relationship between CSI and sales turnover, produced a $p$-value of 0.00001 , indicating a positive and significant association between CSI and sales turnover within the sample of companies. These finding confirms previous findings such as Giannarakis et al. (2017), Yu-Chun (2017), Reverte et al. (2016).

Table 3 produced a p-value of 0.10 ; although this value is more than 0.05 alpha level, which is not significant, the relationship is positively associated with CSI, but this is a weak association. This finding is consistent with previous literature, which found negative relationship (Nakashima \& Ota, 2016; Lakshitha \& Perera, 2016).

These findings bring something new to previous positive findings. This is because the years chosen in this research were five years following the release of South Africa King III code of corporate governance, whose sustainability disclosure aspect was adopted by the Johannesburg Stock Exchange. So these findings shows that companies' CSI initiative following corporate governance code may likely spur their share price performance as investors might be on the watch to observe compliance as they might equally regard the corporate governance code as a potential risk if not complied with. These findings thus contribute to the existing research, as it stands out in the sense that it presents a unique examination different from previous research. It observed companies CSI and financial performance five years following the release of corporate governance code.

\section{CONCLUSION}

The quest for sustainable development requires that companies should contribute to society by engaging in corporate social investment. To this end, research has bourgeoned to assess if companies might have some benefit from CSI initiatives and these researches remain with diverse findings. Hence, this research, which examined how CSI relate financial, became necessary to contribute with results from companies in an emerging economy and compare such with existing research findings. Findings from this research document many previous literature evidence from different countries of positive relationship between CSR and firm performance (e.g., Giannarakis et al., 2017; Yu-Chun, 2017; Reverte et al., 2016). On the contrary, some other previous literature found a negative relationship between CSI and financial performance (e.g. Nakashima \& Ota, 2016; Lakshitha \& Perera, 2016). 
Findings from the analysis concur with previous research findings, but this research brought something new to the existing literature. Unlike other previous research, the research looked at companies' CSI performance against three financial indicators share price, sales turnover and return on equity within five years following release and announcement of South Africa's King III code of corporate governance. Therefore, the findings showed that with the five years following the release of code of corporate governance, companies' CSI improvement was positively associated with financial performance represented by share price and sales turnover. Thus these findings support the literature findings on positive relationship such as Giannarakis et al. (2017), Yu-Chun (2017), Reverte et al. (2016). On the contrary, the analysis show no relationship between CSI and return on equity, which are also in support in some other literature which includes Nakashima and Ota (2016), Lakshitha and Perera (2016). Further findings from the literature does show that conflicting results may arise due to many reasons, which include, amongst others, sources of data, type of data used, time period, sample size, market sustainability awareness and individual country culture. Therefore, the paper recommends that further research should expand on this paper by extending the years to 2017 with more sample of companies and with other methods of analysis to see if the relationship might produce a different result.

\section{REFERENCES}

1. Adams, C. A., Potter, B., Singh, P. J., \& York, J. (2016). Exploring the implications of integrated reporting for social investment (disclosures). The British Accounting Review, 48(3), 283-296.

2. Ağan, Y., Kuzey, C., Acar, M. F., \& Açıkgöz, A. (2016). The relationships between corporate social responsibility, environmental supplier development, and firm performance. Journal of Cleaner Production, 112, 1872-1881.

3. Alafi, K. \& Hasoneh, A. B. (2012). Corporate social responsibility associated with customer satisfaction and financial performance a case study with housing banks in Jordan. International Journal of Humanities and Social Science, 2(15), 102-115.

4. Al-Shammari, H. A. (2006). CEO Option Pay, Risk Taking, and Firm Performance: An Examination of the Moderating Effects of Firm Governance Structure, Strategy, and Environment. Texas: The University of Texas at Arlington.

5. Barnett, M. L., \& Salomon, R. M. (2012). Does it pay to be really good? Addressing the shape of the relationship between social and financial performance. Strategic Management Journal, 33(11), 1304-1320.
6. Bhimani, A., Silvola, H., \& Sivabalan, P. (2016). Voluntary corporate social responsibility reporting: A study of early and late reporter motivations and outcomes. Journal of Management Accounting Research, 28(2), 77-101.

7. Blackburn, V. L., Doran, M., \& Shrader, C. B. (1994). Investigating the dimensions of social responsibility and the consequences for corporate financial performance. Journal of Managerial Issues, 195-212.

8. Bowen, H. R. (2013). Social responsibilities of the businessman. University of Iowa Press, Lowa City.

9. Callan, S. J., \& Thomas, J. M. (2009). Corporate financial performance and corporate social performance: an update and reinvestigation. Corporate Social Responsibility and Environmental Management, 16(2), 61-78.

10. Charlo, M. J., Moya, I., \& Muñoz, A. M. (2015). Sustainable development and corporate financial performance: a study based on the FTSE4Good IBEX Index. Business Strategy and the Environment, 24(4), 277-288.

11. De Klerk, M., de Villiers, C., \& van Staden, C. (2015). The influence of corporate social responsibility disclosure on share prices: evidence from the United Kingdom. Pacific Accounting Review, 27(2), 208-228.

12. De MaCarty, P. (2009). Financial returns of corporate social responsibility, and the moral freedom and responsibility of business leaders. Business and Society Review, 114(3), 393-433.

13. European Commission: Directorate-General for Employment. (2001). Promoting a European Framework for Corporate Social Responsibility: Green Paper. Office for Official Publications of the European Communities.

14. Falck, O., \& Heblich, S. (2007). Corporate social responsibility: Doing well by doing good. Business Horizons, 50(3), 247-254.

15. Firli, A., \& Akbar, N. (2016). Does Corporate Social Responsibility Solve ROA Problem in Indonesia Telecommunication Industry? American Journal of Economics, 6(2), 107-115

16. Franks, D. M., Davis, R., Bebbington, A. J., Ali, S. H., Kemp, D., \& Scurrah, M. (2014). Conflict translates environmental and social risk into business costs. Proceedings of the National Academy of Sciences, 111(21), 7576-7581. 
17. Friedman, M. (2007). The social responsibility of business is to increase its profits. In Corporate ethics and corporate governance (pp. 173-178). Berlin Heidelberg: Springer.

18. Giannarakis, G., Konteos, G., Zafeiriu, E., \& Partalidou, X. (2016). The impact of corporate social responsibility on financial performance. Investment Management and Financial Innovations, 13(3), 171-182. https:// doi.org/10.21511/imfi.13(31). 2016.03

19. Giannarakis, G., Konteos, G., Zafeiriu, E., \& Partalidou, X. (2017). The effect of Dow Jones Sustainability Index on consumer Investment Management and Financial Innovation, 14(1), 8995. http://dx.doi.org?10.21511/ imfi.13(3-1).2016.03

20. Henderson, R. (2015). Making the Business Case for Environmental Sustainability. Retrieved from http:// www.hbs.edu/faculty/Publication\%20Files/15-068_c417331e2146-40b6-8dfc-aa9a029db119.pdf

21. Hirsch, S. (2017). Successful in the long run: a meta-regression analysis of persistent firm profits. Journal of Economic Surveys. Retrieved from http://onlinelibrary.wiley.com/ doi/10.1111/joes.12188/full

22. Hubbard, T. D., Christensen, D. M., \& Graffin, S. D. (2017). Higher highs and lower lows: the role of corporate social responsibility in CEO Dismissal. Strategic Management Journal. https://doi. org/10.1002/smj.2646

23. Mynhardt, H., Makarenko, I., \& Plastun, A. (2017). Market efficiency of traditional stock market indices and social responsible indices: the role of sustainability reporting. Investment Management and Financial Innovations, 14(2), 94-106. https://doi.org/10.21511/ imfi.14(2).2017.09

24. Hirschheim, R., Heinzl, A., \& Dibbern, J. (Eds.). (2009). Information systems outsourcing: enduring themes, global challenges, and process opportunities. Springer Science \& Business Media.

25. Herek, A. G. (2012). A brief introduction to sampling. Retrieved from http://psychology.ucdavis.edu/ rainbow/html/fact_sample.html

26. IDS (Institute of Directors in Southern Africa) (2013). King III reporting in terms of the JSEListings Requirements. Retrieved from https://www.jse. co.za/content/JSEGuidanceLettersItems/King\%20III\%20Reporting $\% 20$ in $\% 20$ terms $\% 20$ of $\% 20$ the\%20JSE\%20Listings\%20Requirements.pdf

27. Kecskes, A., Mansi, S., \& Nguyen, P. A. (2016). Can Firms Do Well for Shareholders by Doing Good for Stakeholders? The Importance of Long-Term Investors. Retrieved from https://papers.ssrn.com/sol3/ papers.cfm?abstract_id $=2344308$

28. Kim, Y., Li, H., \& Li, S. (2014). Corporate social responsibility and stock price crash risk. Journal of Banking \& Finance, 43, 1-13.

29. Lee, E., Walker, M., \& Zeng, C. C. (2017). Do Chinese state subsidies affect voluntary corporate social responsibility disclosure? Journal of Accounting and Public Policy, 36(3), 179-200.

30. Lins, K. V., Servaes, H., \& Tamayo, A. (2016). Social capital, trust, and firm performance: The value of corporate social responsibility during the financial crisis. Retrieved from https://papers.ssrn. com/sol3/papers.cfm?abstract_ $\mathrm{id}=2555863$

31. Lakshitha, W. R., \& Perera, H. A. P. L. (2016). Impact of Corporate Social Responsibility on Firm Financial Performance: Evidence from the Listed Manufacturing Companies in Sri Lanka. Retrieved from http://repository.kln.ac.lk/ handle/123456789/16497

32. Manchiraju, H., \& Rajgopal, S. (2017). Does Corporate Social Responsibility (CSR) Create Shareholder Value? Evidence from the Indian Companies Act 2013. Journal of Accounting Research.

33. Mondi. (2012). Sustainability report 2012. Retrieved from https:// sd-report.mondigroup.com/2012/ social/society/corporate-socialinvestment

34. Nakashima, M., \& Ota, S. (2016). Association Between Corporate
Financial Performance And Corporate Social Responsibility In A Crisis: Focusing on the March 11 Disaster. Asia-Pacific Management Accounting Journal, 11(2).

35. Orlitzky, M., Schmidt, F. L., \& Rynes, S. L. (2003). Corporate social and financial performance: A meta-analysis. Organization studies, 24(3), 403-441.

36. Perrini, F., Russo, A., Tencati, A., \& Vurro, C. (2011). Deconstructing the relationship between corporate social and financial performance. Journal of Business Ethics, 102(1), 59-76.

37. Reverte, C., Gómez-Melero, E., \& Cegarra-Navarro, J. G. (2016). The influence of corporate social responsibility practices on organizational performance: evidence from Eco-Responsible Spanish firms. Journal of Cleaner Production, 112, 2870-2884.

38. Stout, L. A. (2012). The shareholder value myth: How putting shareholders first harms investors, corporations, and the public. BerrettKoehler Publishers.

39. Solomon, J., \& Maroun, W. (2012). Integrated reporting: the influence of King III on social, ethical and environmental reporting. Retrieved from https://research-repository. st-andrews.ac.uk/bitstream/handle/10023/3749/ACCA-2012-Integrated-Reporting.pdf

40. Wang, H., Lu, W., Ye, M., Chau, K. W., \& Zhang, X. (2016). The curvilinear relationship between corporate social performance and corporate financial performance: Evidence from the international construction industry. Journal of Cleaner Production, 137, 1313-1322.

41. Yu-Chun, L. (2017). Does R\&D investment under corporate social responsibility increase firm performance? Investment Management and Financial Innovations, 14(1-1), 217-226. https://doi.org/10.21511/imfi.14(11). 2017.08

42. Yakovleva, N. (2017). Corporate social responsibility in the mining industries. Routledge, New York. 